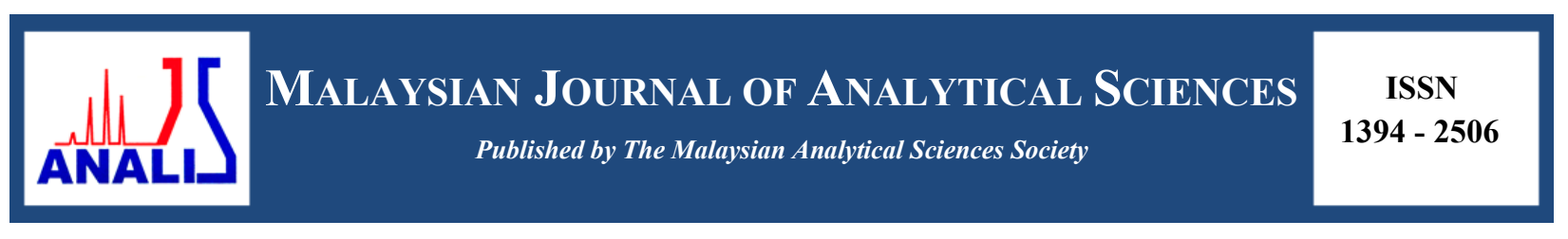

\title{
EXTRACTION OF BIOACTIVE COMPOUNDS (MANGIFERIN) FROM MAHKOTA DEWA (Phaleria macrocarpa) FRUITS USING SUBCRITICAL WATER: EFFECT OF PROCESS PARAMETERS ON EXTRACTION YIELD
}

\author{
(Pengekstrakan Bahan Bioaktif (Mangiferin) dari Buah Mahkota Dewa (Phaleria macrocarpa) \\ Menggunakan Kaedah Air Subgenting: Kesan Parameter Proses Terhadap Hasil Ekstrak) \\ Nurmaryam Aini Hashim, Ummi Najihah Md. Hashim, Siti Kholijah Abdul Mudalip*, Noorlisa Harun, \\ Fatmawati Adam, Rohaida Che Man, Siti Zubaidah Sulaiman, Zatul Iffah Mohd Arshad, Shalyda Md. Shaarani
}

Faculty of Chemical Engineering \& Natural Resources, Universiti Malaysia Pahang, Lebuh Raya Tun Razak, 26300 Gambang, Pahang, Malaysia

*Corresponding author: kholijah@ump.edu.my

Received: 28 November 2016; Accepted: 5 February 2017

\begin{abstract}
Mahkota Dewa (Phaleria macrocarpa) is a popular herbal plant that is indigenous to Indonesia and Malaysia. The bioactive ingredients in the plant contain antihistamine, antioxidant, and anti-cancer compound. In this work, experimental study was performed using subcritical water extraction (SWE) method to extract bioactive compound namely mangiferin from Mahkota Dewa fruits. A sequential screening strategy using one-factor-at-a-time (OFAT) was carried out at different solid to solvent ratios $(30-70 \mathrm{~g} / \mathrm{L})$, temperatures $\left(50-150{ }^{\circ} \mathrm{C}\right)$ and extraction times $(3-7$ hours $)$. The yield of mangiferin extracted was measured using high performance liquid chromatography (HPLC). The results show that the solid to solvent ratio, extraction temperature and time cause significant effect on the mangiferin yield. The best operating conditions for extracting Mahkota Dewa fruit with subcritical method is $60 \mathrm{~g} / \mathrm{L}$ solid to solvent ratio and $100^{\circ} \mathrm{C}$ extraction temperature for 5 hours with mangiferin yield of $3.202 \%$ w/w.
\end{abstract}

Keywords: Mahkota Dewa, subcritical water extraction, mangiferin, one factor at a time

\section{Abstrak}

Mahkota Dewa (Phaleria macrocarpa) adalah tumbuhan herba yang popular berasal dari Indonesia dan Malaysia. Bahan bioaktif yang boleh didapati dalam ekstrak tumbuhan ini adalah seperti antihistamin, antioksidan, dan juga anti-kanser. Dalam kerja penyelidikan ini, satu eksperimen telah dijalankan dengan menggunakan proses pengekstrakan air subgenting (SWE), untuk mengekstrak bahan bioaktif daripada buah Mahkota Dewa iaitu mangiferin. Proses saringan secara berturutan dengan menggunakan kaedah satu-faktor-pada-satu-masa (OFAT) telah dijalankan pada pelbagai nisbah pepejal kepada pelarut (30 - 70 $\mathrm{g} / \mathrm{L})$, suhu $\left(50-150^{\circ} \mathrm{C}\right)$ dan masa pengekstrakan $(3-7$ jam $)$. Hasil ekstrak mangiferin dianalisis dengan menggunakan kaedah kromatografi cecair berprestasi tinggi (HPLC). Hasil analisa menunjukkan bahawa nisbah pepejal kepada pelarut, suhu pengekstrakan dan masa memberi kesan yang besar ke atas hasil ekstrak mangiferin itu. Parameter eksperimen yang terbaik untuk mengekstrak buah Mahkota Dewa dengan menggunakan kaedah subgenting adalah pada nisbah pepejal kepada pelarut 60 $\mathrm{g} / \mathrm{L}$ dan suhu ekstrak pada $100{ }^{\circ} \mathrm{C}$ selama 5 jam dengan hasil ekstrak mangiferin sebanyak $3.202 \% \mathrm{w} / \mathrm{w}$.

Kata kunci: Mahkota Dewa, pengekstrakan air subgenting, mangiferin, satu faktor pada satu masa 


\section{Nurmaryam Aini et al: EXTRACTION OF BIOACTIVE COMPOUNDS (MANGIFERIN) FROM MAHKOTA DEWA (Phaleria macrocarpa) FRUITS USING SUBCRITICAL WATER: EFFECT OF PROCESS PARAMETERS ON EXTRACTION YIELD}

\section{Introduction}

In Malaysia, more than 2000 plant species exist possess healing properties and extensive potential to be commercialized. Phaleria macropcarpa or else known as Mahkota Dewa is one of typical herbal plants that are highly in demand nowadays. Mahkota Dewa is an Indonesia plant of Thymelaceae family that grow in the topical areas of Papua Island [1,2]. Though originated from Indonesia, due to the resemblance of climate, Mahkota Dewa can be easily cultivated and discovered in Malaysia. Mahkota Dewa as illustrated in Figure 1(a) is a complete tree with stem, leaves, flowers, and also fruits. Normal height for Mahkota Dewa tree ranges from 1 to $6 \mathrm{~m}$ with productive age ranges from 10 to 20 years $[1,3,4]$. Its leaves are green and elongated with the length and width ranging from 7 to $10 \mathrm{~cm}$ and 3 to $5 \mathrm{~cm}$, respectively. Fruits of Mahkota Dewa, as illustrated in Figure 1 (a), are green when unripe and turn to red once ripening. It's brown and anatropous seed exist as 1 to 2 seed per fruit [3]. Mahkota Dewa fruits contain ranges of chemical constituents include saponin, flavoid, polyphenol, alkaloid and mangiferin $[3,5]$.

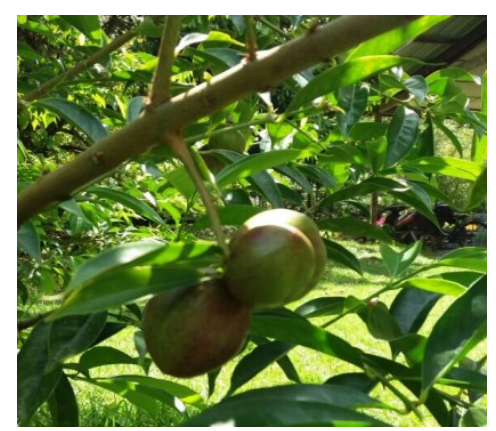

(a)<smiles>O=c1c2cc(O)c(O)cc2oc2cc(O)c(C3OC(CO)C(O)C(O)C3O)c(O)c12</smiles>

(b)

Figure 1. (a) Mahkota Dewa (Phaleria macrocarpa) fruits and (b) molecular structure of Mangiferin

Among the bioactive compounds, mangiferin as illustrated in Figure 1(b), has an extensive range of pharmacological effects including anti-inflammation, antioxidant, anti-diabetic, anti-tumor and also anticancer activity [5-7]. Mangiferin $\left(\mathrm{C}_{19} \mathrm{H}_{18} \mathrm{O}_{11}\right)$ is reported as a heat stable molecule and it's natural pharmacological active compound has been proven to have various biological benefits [8]. Despite its beneficial bioactive effect, only few researches [5,9] reported the extraction of bioactive compounds from Mahkota Dewa using conventional extraction method. Considering the benefits of the plant extraction, it is necessary to explore other alternative method to extract the bioactive compounds.

Extraction method can be further divided into two, which is a conventional and non-conventional method. Conventional techniques is a classical existing techniques based on the extracting power of different solvents in use and also the application of heat and/or mixing towards the target plant [10]. It can be further classified into hydrodistillation, maceration and soxhlet extraction. This technique are still being practiced as a comparison technique to non-conventional methods [10,11]. Non-conventional such as microwave assisted extraction (MAE), ultrasound-assisted extraction (UAE) and subcritical water extraction (SWE) methods are reported to have more advantages compared to the conventional techniques $[10,12,13]$. These includes environmental friendly and cost efficient due to less usage of synthetic and organic chemical, short operational time, higher yield and good extract quality $[10,12-14]$.

Previous work demonstrates the usage of organic solvent like methanol and ethanol as extraction solvent $[15,16]$. Due to long extraction time, low extraction yield, and residual toxic problem, the urge to develop new non-organic solvent-based extraction methods with higher extraction efficiency is needed. Subcritical water extraction (SWE) implements use of green solvent such as water and it is well known as environmental-friendly and non-toxic solvent. Water demonstrates exceptional properties as it has high boiling point for its mass, high polarity and high 
dielectric constant $[17,18]$. SWE promote shorter extraction time, higher quality of extract and lower extraction cost at temperature between $100{ }^{\circ} \mathrm{C}$ to $374{ }^{\circ} \mathrm{C}$. By increasing the temperature at moderate pressure, it reduces the surface tension and viscosity, and increasing its diffusion rate causes SWE is comparable to organic solvents $[17,19]$.

Recently, it has been reported that extraction efficiency of triterpenes from dry loquat leaves using SWE method produced yield of 1.7 times higher than those obtained using traditional methods which was soxhlet extraction (SE) [18]. The aim of this research work was to demonstrate the extraction of mangiferin from Mahkota Dewa using subcritical water extraction approach. The effect of solid to solvent ratio, temperature, and time on extraction yields of mangiferin was investigated. The results obtained would be useful as alternative experimental design to extract and analysis plant material, for further analysis in form of making the process more efficient and to increase the process economy.

\section{Materials}

\section{Materials and Methods}

Dried Mahkota Dewa (Phaleria macrocarpa) fruits were supplied by Ethno Resources Malaysia Sdn. Bhd. (Petaling jaya, Malaysia). Mahkota Dewa provided were planted in Selangor, Malaysia. The dried Mahkota Dewa was ground with Ultra Centrifugal Mill ZM 200 (Haan, German) to an average size of $500 \mu \mathrm{m}$. HPLC grade methanol (99.9\% purity) and ortho-phosphoric acid (85\% purity) purchased from Permula Chemicals Sdn. Bhd (Kuantan, Malaysia). Mangiferin (1S-1,5-Anhydro-1-(1,3,6,7-tetrahydroxy-9-oxo-9H-xanthen-2-yl)-D-glucitol) standard and 2,2-diphenyl-1-picrylhydrazyl (DPPH) were purchased from Merck (Selangor, Malaysia). All chemicals were used without further purification. Deionized water was prepared using a Milli-Q, Ultrapure Water Purification System (Massachusetts, USA) with a $0.22 \mathrm{~mm}$ filter. The $0.2 \mu \mathrm{m}$ nylon membrane filter and $0.45 \mu \mathrm{m}$ nylon syringe filter used in sample preparation prior to HPLC analysis were supplied by MHY Energy Resources (Kuantan, Malaysia).

\section{Subcritical water extraction}

A classical approach one-factor-at-a-time (OFAT) was used to determine the optimum range of the selected process parameters during the SWE process. Through this technique, one level of the factor to be investigated was changed over the desired range and at the same time keeping the level of other factors constant [20]. SWE experiments were performed in a $10 \mathrm{~cm}(\mathrm{~W})$ × $20 \mathrm{~cm}(\mathrm{H})$ stainless steel batch Buchiglasuster Kiloclave laboratory pressure vessel reactor system (Uster, Switzerland) as illustrated in Figure 2. The vessel can be operated within temperature range of $-20^{\circ} \mathrm{C}$ to $250^{\circ} \mathrm{C}$ and can hold up sample up to $2 \mathrm{~L}$. This multipurpose pressure reactor is made up from stainless steel and designed for the use of large steel pressure vessel.

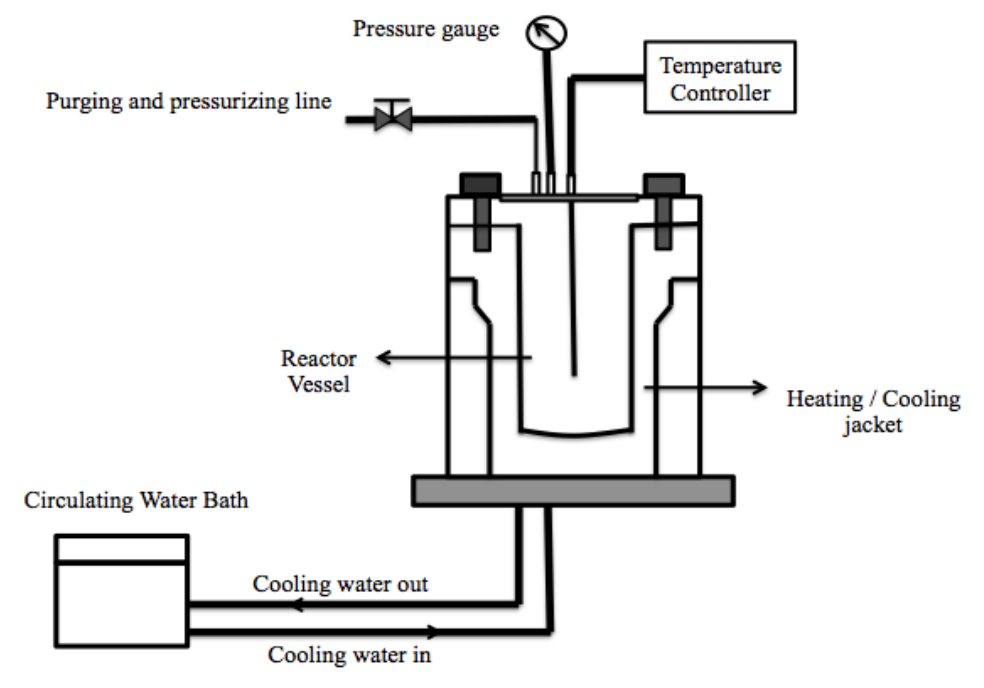

Figure 2. Schematic diagram of Buchiglasuster Kiloclave laboratory reactor system 


\section{Nurmaryam Aini et al: EXTRACTION OF BIOACTIVE COMPOUNDS (MANGIFERIN) FROM MAHKOTA DEWA (Phaleria macrocarpa) FRUITS USING SUBCRITICAL WATER: EFFECT OF PROCESS PARAMETERS ON EXTRACTION YIELD}

Process parameters studied were solid to solvent ratio, temperature and extraction time. Summaries of the parameters investigated at different levels are tabulated in Table 1. Dry ground Mahkota Dewa fruit sample weighed and placed into the extraction vessel. Exact volume of deionized water $(1 \mathrm{~L})$ was added as extraction solvents and mixed thoroughly. Reactor was tightly closed and secured with bolts and nuts. Temperature and time were set at desired value. Once extraction was completed, vessel was allowed to cool to room temperature, $24{ }^{\circ} \mathrm{C}$. Cooling water was supplied using Stuart recirculating cooler RE300RC (Staffordshire, UK). Extract was collected by loosing the nut and bolt of the reactor and then poured into a sample bottle. About $40 \mathrm{~mL}$ of the extract was then poured into the centrifuge tube and centrifuged for $30 \mathrm{~min}$ at $5000 \mathrm{rpm}$ and the rest of the extract stored in $-20{ }^{\circ} \mathrm{C}$ refrigerator. Extract supernatant isolated from precipitate and sonicated for 10 minutes to evenly disperse the particle in water. During the sonication, $10 \mathrm{ml}$ of sonicated extract collected then diluted with $20 \mathrm{~mL}$ of methanol by using syringes. Mixtures filtered using $0.45 \mu \mathrm{m}$ nylon syringe filter into Agilent MS analyzed vial kits (California, USA) and analysed using HPLC. All the experiments performed in triplicates.

Table 1. Summary of process parameters for OFAT

\begin{tabular}{lll}
\hline Parameters & Experimental Conditions & \multicolumn{1}{c}{ Fixed Parameters } \\
\hline Solid to solvent ratio $(\mathrm{g} / \mathrm{L})$ & $30,40,50,60$ and 70 & $\begin{array}{l}\text { Temperature }-100{ }^{\circ} \mathrm{C} \\
\text { Time }-5 \mathrm{~h}\end{array}$ \\
Temperature $\left({ }^{\circ} \mathrm{C}\right)$ & $50,75,100,125$ and 150 & $\begin{array}{l}\text { Solid to solvent ratio }-6: 100 \mathrm{~g} / \mathrm{L} \\
\text { Time }-5 \mathrm{~h} \\
\text { Solid to solvent ratio }-6: 100 \mathrm{~g} / \mathrm{L} \\
\text { Temperature }-100{ }^{\circ} \mathrm{C}\end{array}$ \\
\hline
\end{tabular}

\section{High performance liquid chromatography analysis}

Chemical compound in Mahkota Dewa was determined using HPLC (Agilent Technologies 1100, California, USA). Column used was Zorbax Eclipse Plus C18, Analytical 4.6 X 250 mm, 5 Micron (Agilent Technologies, California, USA). Detection was performed using a diode array detector (DAD). The chromatographic separation was performed at a wavelength of $258 \mathrm{~nm}$. Mobile phase comprises of HPLC grade methanol and $0.1 \%$ aqueous phosphoric acid with a ratio of 31:69 and filtered with $0.2 \mu \mathrm{m}$ nylon membrane filter prior to analysis. Mobile phase flow rate was set at $1.0 \mathrm{~mL} / \mathrm{min}$ with amount of sample injection of $10 \mu \mathrm{L}$. HPLC unit was calibrated with mangiferin standard solution prepared prior to each analysis at different concentrations. Standard solution was prepared by diluting $5.0 \mathrm{mg}$ of mangiferin standard with $10 \mathrm{~mL}$ methanol to produced $500 \mathrm{ppm}$ of concentration [5]. This mixture was then diluted into several concentrations (5 to $60 \mathrm{ppm})$ and was used to construct a calibration curve. HPLC chromatogram of mangiferin standard and Mahkota Dewa extract are shown in Figure 3. The relationship between peak area, $x$ and concentration of mangiferin, $y$ can be represented by a linear equation as follows:

$$
y=15.806 x\left(\mathrm{R}^{2}=0.99482\right)
$$




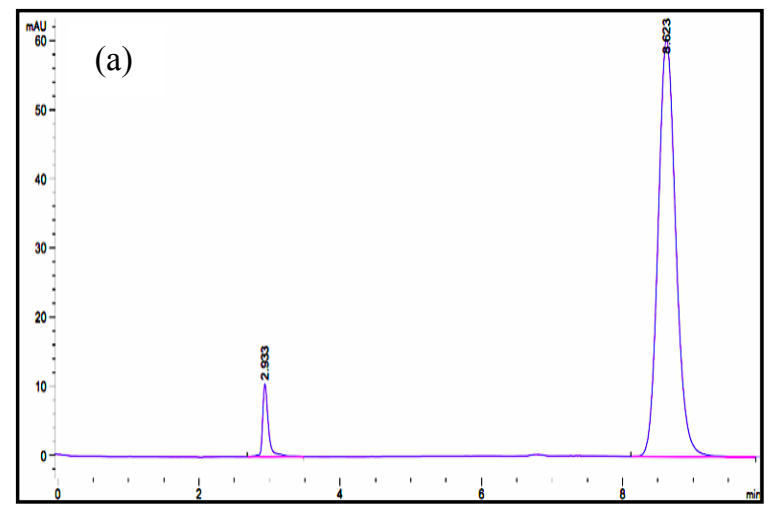

Retention time, min

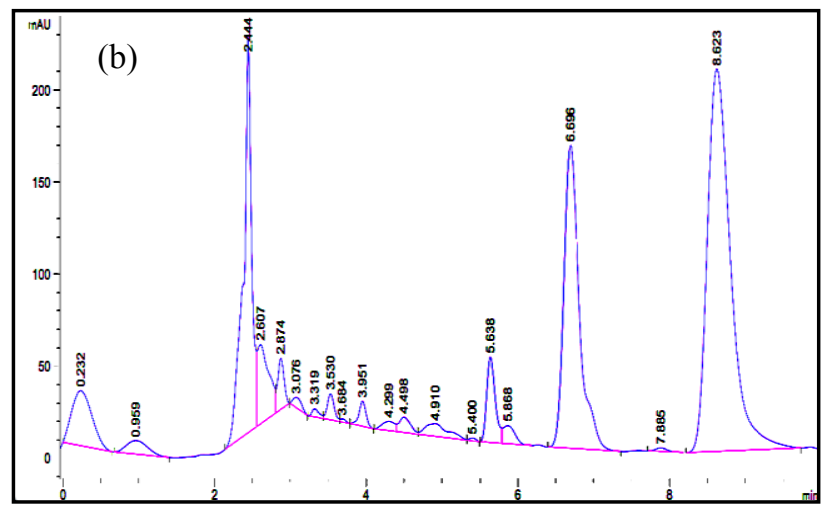

Retention time, $\min$

Figure 3. HPLC chromatogram of (a) mangiferin standard and (b) Mahkota Dewa extract. The peak at retention time of of $8.623 \mathrm{~min}$ was used to estimate the mangiferin yield

\section{The effect of solid to solvent ratio}

\section{Results and Discussion}

The results show that among solid to solvent ratio tested, $60 \mathrm{~g} / \mathrm{L}$ was most effective. Figure 4 shows the effect of solid to solvent ratio on the mangiferin yield. Mangiferin yield was increased from $0.962 \% \mathrm{w} / \mathrm{w}$ to $1.8718 \% \mathrm{w} / \mathrm{w}$ at solid to solvent ratio of 30 to $60 \mathrm{~g} / \mathrm{L}$. However, the mangiferin yield was reduced to $1.524 \% \mathrm{w} / \mathrm{w}$ at the solid to solvent ratio of $70 \mathrm{~g} / \mathrm{L}$. The removal of solute require a lot of energy using water as solvent, consequently if more water used in an extraction, it may lead to higher energy consumption [21]. In general, the higher the amount of solid in a solvent would reflect the higher amount extraction yield. This statement is in agreement with the mass transfer principle, where its driving force depends on the concentration gradient between solute and the solvent $[22,23]$. High solid to solvent ratio produce high concentration gradient, thus cause an increase of diffusion rate, which allows greater extraction of solute by solvent [11,12]. The decrease of mangiferin yield beyond solid to solvent ratio of $60 \mathrm{~g} / \mathrm{L}$ is probably due to low extraction efficiency, where the solvent was not sufficient enough to dissolve the solute and the equilibrium of solute and solvent was achieved [11]. Equilibrium of solute and solvent defined as a condition where no further changes in either phase will occur for the solid and solvent phases [17,2426]. Smaller volumes of solvent can lead to incomplete target extraction while larger volumes can make the extraction procedure becomes complex and wasteful. This findings is in agreement with Zhang et al. [27] which stated that the chance of bioactive components come into contact with the extracting solvent is increase with the increase amount of solute and will not continue to increase once equilibrium is reached.

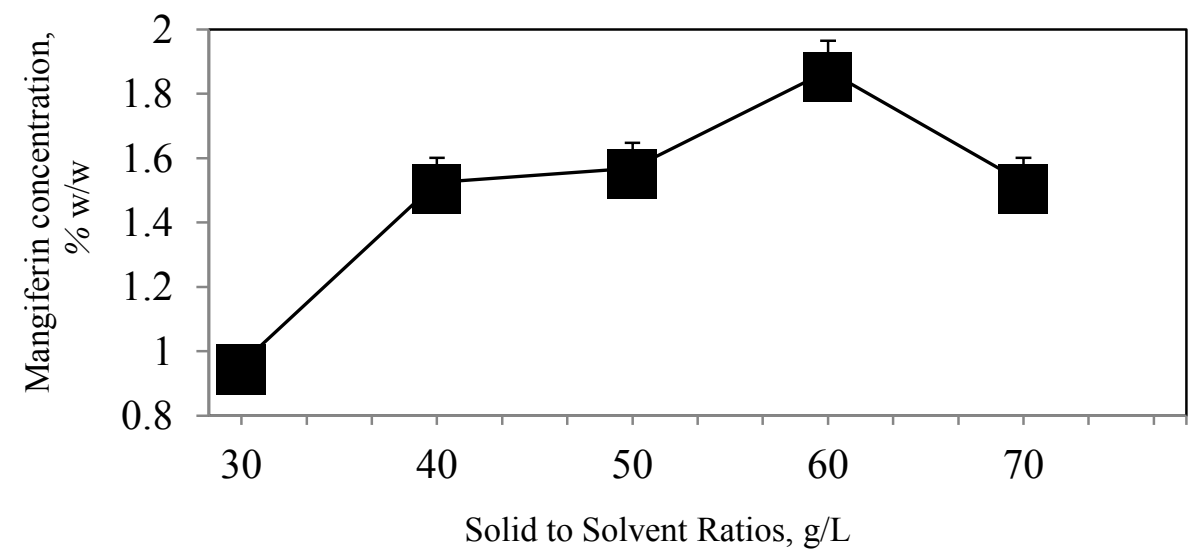

Figure 4. Effects of different solid to solvent ratio on mangiferin yield. The extraction temperature and time were fixed at $100{ }^{\circ} \mathrm{C}$ and 5 hours, respectively. Values are mean \pm standard deviations 


\section{Nurmaryam Aini et al: EXTRACTION OF BIOACTIVE COMPOUNDS (MANGIFERIN) FROM MAHKOTA DEWA (Phaleria macrocarpa) FRUITS USING SUBCRITICAL WATER: EFFECT OF PROCESS PARAMETERS ON EXTRACTION YIELD}

\section{The effect of temperature}

Figure 5 illustrates the effect of extraction temperatures on the mangiferin yield. It can be seen that the yield of mangiferin increase with the increase of temperature from $50{ }^{\circ} \mathrm{C}$ up to $100{ }^{\circ} \mathrm{C}$. The highest mangiferin yield $(2.405 \% \mathrm{w} / \mathrm{w})$ was obtained at extraction temperature of $100{ }^{\circ} \mathrm{C}$. At temperature of $125{ }^{\circ} \mathrm{C}$ and $150{ }^{\circ} \mathrm{C}$, a slight decreased of mangiferin yield was observed with the yield of $1.827 \% \mathrm{w} / \mathrm{w}$ and $1.435 \% \mathrm{w} / \mathrm{w}$, respectively. Both the equilibrium (solubility) and mass transfer rate (diffusion coefficient) can affect the extraction temperature and high temperature is often associated with the increase rate of diffusivity and solubilization of solute but decrease in the viscosity and surface tension of solvent. In theory, the penetrability and solubility of the solvents increased with the increase of the temperature, thus resulting in an increased of extraction efficiency and speed. Increase in yield with respect to increasing temperature is attributed to thermal kinetics of mass transfer and the thermodynamic effect of temperature on solubilization [21]. Therefore, extraction process that performed at high temperature often shows an increment in yield. According to Gbashi et al. [19], it is recommended to extract at the high permitted temperature since low temperature result in low diffusivity and consequently low extraction yield [18-20]. Consistent with previous works yield decreases as operating temperature exceeds $100{ }^{\circ} \mathrm{C}[21,30]$. The main disadvantage of applying higher temperature is the increase of the solvent boil off and reducing effective contact area between solid and liquid phases. As a result, lower yield of the final extracts [21]. This extraction process aiming to extract mangiferin compound and water temperature does not necessarily have to be high as possible, all of the parameter should be optimized and carefully controlled [31]. It is suggested that the best operational temperature that yield highest amount of mangiferin was at $100{ }^{\circ} \mathrm{C}$ with extraction yield of $2.405 \% \mathrm{w} / \mathrm{w}$.

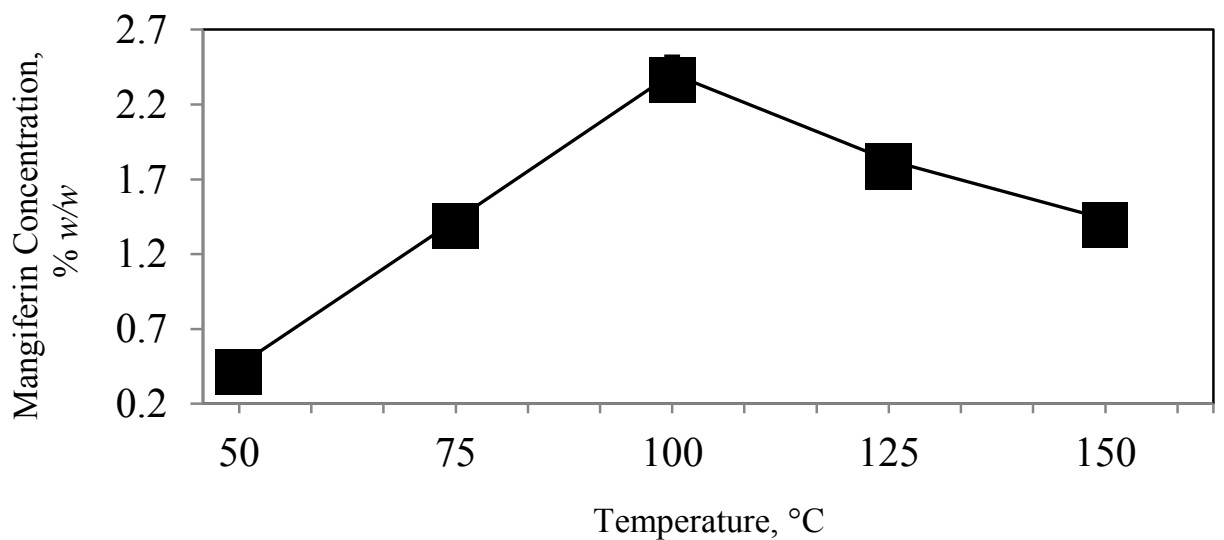

Figure 5. Effects of different temperature on mangiferin yield. The extraction solid to solvent ratio and time were fixed at $60 \mathrm{~g} / \mathrm{L}$ and $5 \mathrm{~h}$, respectively. Values are mean \pm standard deviations

\section{The effect of time}

The extraction process was carried out at different times with fixed solid to solvent ratio of $60 \mathrm{~g} / \mathrm{L}$ and temperature of $100{ }^{\circ} \mathrm{C}$. The results illustrated in Figure 6 show a significant increment of extraction yield from extraction time of 3 hours $(2.506 \% \mathrm{w} / \mathrm{w})$ to extraction time of 5 hours $(3.202 \% \mathrm{w} / \mathrm{w})$. Further increase of the extraction time, which is from 6 to 7 hours reduced the mangiferin yield to $2.631 \% \mathrm{w} / \mathrm{w}$. It is essential to determine the duration of the extraction process required to extract most of the desired bioactive compounds. Under static extraction, equilibrium among the sample components was still bound to the matrix and the water phase, in which the components are already solubilized, might be reached [28,29]. By using this information, suitable duration can be selected and operating cost for the process can be reduced [21]. Based on the result, the efficiency of the extraction time was not increase within 5 hours of extraction and since most bioactive compounds are sensitive to elevated temperature, keeping them for a longer period would lead to the thermal decomposition of the bioactive compounds. For this reason, best extraction time for subcritical water extraction of Mahkota Dewa is 5 hours with yield of 3.202\% w/w 
of mangiferin. This results as further support the finding reported by Tunchaiyaphum et al. [29] and Kim et al. [5] who found that the degradation of extracted compound at prolonged extraction time.

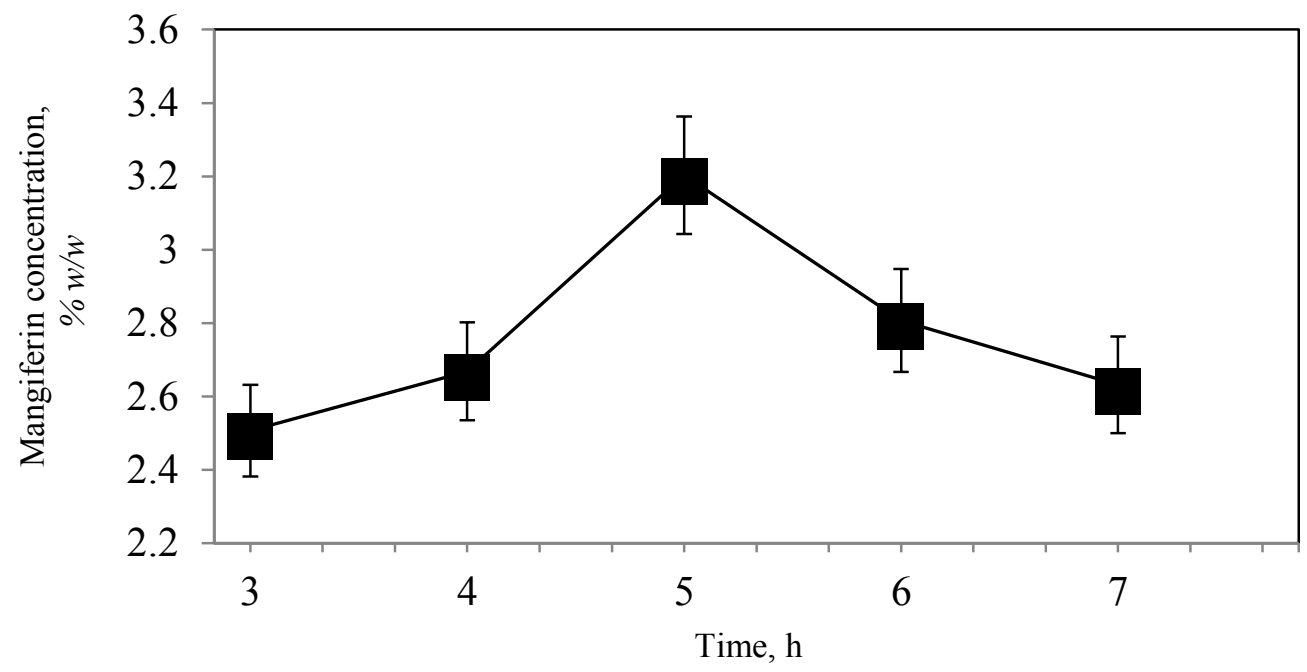

Figure 6. Effects of different time on mangiferin yield. The extraction solid to solvent ratio and temperature were fixed at $60 \mathrm{~g} / \mathrm{L}$ and $100{ }^{\circ} \mathrm{C}$, respectively. Values are mean \pm standard deviations

\section{Conclusion}

The effect of process parameters in extracting mangiferin from Mahkota Dewa fruits, i.e., solid to solvent ratio, extraction temperature, and time on a subcritical water extraction (SWE) batch extraction of have been investigated. In general, solid to solvent ratio, extraction temperature, and extraction time was found to show significant effect on the amount of mangiferin extracted from Mahkota Dewa fruits. The increased of the solid to solvent ratio, extraction temperature, and extraction time up to certain extent, increased the mangiferin yield. The best operating parameters that produced the highest mangiferin yield of $3.202 \% \mathrm{w} / \mathrm{w}$ ) were at $60 \mathrm{~g} / \mathrm{L}$ of solid to solvent ratios, extraction temperature of $100^{\circ} \mathrm{C}$ and extraction time of 5 hours.

\section{Acknowledgement}

The authors are grateful for the financial support from the Ministry of Education Malaysia for Research Acculturation Grant Scheme (Grant No. RDU151402). We also appreciate the Faculty of Chemical and Natural Resources Engineering, Universiti Malaysia Pahang for the research facilities.

\section{References}

1. Anggraini, T. and Lewandowsky, P. (2015). The exotic plants of Indonesia: Mahkota Dewa (Phaleria macrocarpa), Sikaduduak (Melastoma malabathricum Linn) and Mengkudu (Morinda citrifolia) as potent antioxidant sources. International Journal on Advanced Science Engineering Information Technology, 5(2): $59-62$.

2. Tandrasasmita, O. M., Lee, J. S., Baek, S. H. and Tjandrawinata, R. R. (2010). Induction of cellular apoptosis in human breast cancer by DLBS1425, a Phaleria macrocarpa compound extract, via downregulation of PI3kinase/AKT pathway. Cancer Biology and Therapy, 10(8): $814-824$.

3. Altaf, R., Zaini, M., Asmawi, B., Dewa, A., Sadikun, A. and Umar, M. I. (2013). Phytochemistry and medicinal properties of Phaleria macrocarpa (Scheff.) Boerl. extracts. Pharmacognosy Reviews, 7(13), $73-80$.

4. Zhang, Y.-B., Xu, X.-J. and Liu, H.-M. (2006). Chemical constituents from Mahkota dewa. Journal of Asian Natural Products Research, 8(1-2): $119-123$.

5. Kim, W., Veriansyah, B., Lee, Y., Kim, J. and Kim, J. (2010). Extraction of mangiferin from Mahkota Dewa (Phaleria macrocarpa) using subcritical water. Journal of Industrial and Engineering Chemistry, 16(3), $425-430$. 
6. Dai, J. and Mumper, R. J. (2010). Plant phenolics: Extraction, analysis and their antioxidant and anticancer properties. Molecules, 15(10): 7313 - 7352.

7. Mirza, R. H., Chi, N. and Chi, Y. (2013). Therapeutic potential of the natural product mangiferin in metabolic syndrome. Journal of Nutritional Therapeutics, 2: $74-79$.

8. Luo, F., Lv, Q., Zhao, Y., Hu, G., Huang, G. and Zhang, J. (2012). Quantification and purification of mangiferin from Chinese Mango (Mangifera indica L.) cultivars and its protective effect on human umbilical vein endothelial cells under $\mathrm{H}_{2} \mathrm{O}_{2}$-induced stress. International Journal of Molecular Sciences, 13: $11260-11274$.

9. Andrean, D., Prasetyo, S., Kristijarti, A. P. and Hudaya, T. (2014). The extraction and activity test of bioactive compounds in Phaleria macrocarpa as antioxidants. Procedia Chemistry, 9: $94-101$.

10. Azmir, J., Zaidul, I. S. M., Rahman, M. M., Sharif, K. M., Mohamed, A., Sahena, F., Jahurul, M.H.A., Ghafoor, K., Norulaini, N. A. N. and Omar, A. K. M. (2013). Techniques for extraction of bioactive compounds from plant materials: A review. Journal of Food Engineering, 117(4): 426 - 436.

11. Nayak, B., Dahmoune, F., Moussi, K., Remini, H., Dairi, S., Aoun, O. and Khodir, M. (2015). Comparison of microwave, ultrasound and accelerated-assisted solvent extraction for recovery of polyphenols from Citrus sinensis peels. Food Chemistry, 187: $507-516$.

12. Bimakr, M., Rahman, R. A., Saleena Taip, F., Adzahan, N. M., Islam Sarker, Z. and Ganjloo, A. (2013). Ultrasound-assisted extraction of valuable compounds from winter melon (Benincasa hispida) seeds. International Food Research Journal, 20(1): 331 - 338.

13. Fazlali, A., Moradi, S. and Hamedi, H. (2015). Studying of optimization condition of rosemary essence extraction with microwave assisted hydro-distillation method. American Journal of Essential Oils and Natural Products, 3: $46-50$.

14. Eikani, M. H., Golmohammad, F. and Rowshanzamir, S. (2007). Subcritical water extraction of essential oils from coriander seeds (Coriandrum sativum L.). Journal of Food Engineering, 80(2): 735 - 740.

15. Kubátová, A., Miller, D. J. and Hawthorne, S. B. (2001). Comparison of subcritical water and organic solvents for extracting kava lactones from kava root. Journal of Chromatography A, 923(1-2): 187 - 194.

16. Lay, M. M., Karsani, S. A., Banisalam, B., Mohajer, S. and Abd Malek, S. N. (2014). Antioxidants, phytochemicals, and cytotoxicity studies on Phaleria macrocarpa (Scheff.) Boerl Seeds. BioMed Research International, 2014: 1 - 13.

17. Asl, A. H. and Khajenoori, M. (2013). Subcritical water extraction. mass transfer - advances in sustainable energy and environment oriented numerical modeling. InTech Publisher.

18. Erasto, M., Shuang, Z., Zongping, Z. and Jie, C. (2016). Subcritical water extraction of bioactive compounds from dry loquat (Eriobotrya japonica) leaves and characterization of triterpenes in the extracts. African Journal of Biotechnology, 15(22): 1041 - 1049.

19. Gbashi, S., Adebo, O. A., Piater, L., Madala, N. E. and Njobeh, P. B. (2016). Subcritical water extraction in biological materials. Separation and Purification Reviews, 46(1): 21-34.

20. Czitrom, V. (1999). One-factor-at-a-time versus designed experiments. American Statistical Association, 53(2): $65-74$.

21. Mohamad, M., Ali, M. W., Ripin, A. and Ahmad, A. (2013). Effect of extraction process parameters on the yield of bioactive compounds from the roots of Eurycoma Longifolia. Jurnal Teknologi, 60: 51-57.

22. Saim, N., Osman, R., Azriza, W., Yasin, H. and Hamid, R. D. (2008). Subcritical water extraction of essential oil from coriander (Coriandrum sativum L.) seeds. Malaysian Journal of Analytical Sciences, 12(1): 22 - 24.

23. Wong, B. Y., Tan, C. P. and Ho, C. W. (2013). Effect of solid-to-solvent ratio on phenolic content and antioxidant capacities of "Dukung Anak" (Phyllanthus niruri). International Food Research Journal, 20(1): $325-330$.

24. Toledo, R. (2007). Fundamentals of food process engineering. Springer, Athens, USA.

25. Zhang, S. Q., Bi, H. M. and Liu, C. J. (2007). Extraction of bio-active components from Rhodiola sachalinensis under ultrahigh hydrostatic pressure. Separation and Purification Technology, 57(2): $277-282$.

26. Fariza, N., Luqman, C. A., Ky, P., Dayang, R. Ab., Umi, K. and Adawiah, I. (2014). Optimisation of extraction of Phaleria macrocarpa leaves. Medicinal \& Aromatic Plants, 3(1): 1 - 3.

27. Gong, Y., Zhang, X., He, L., Yan, Q., Yuan, F. and Gao, Y. (2015). Optimization of subcritical water extraction parameters of antioxidant polyphenols from sea buckthorn (Hippophaë rhamnoides L.) seed residue. Journal of Food Science and Technology, 52(3): 1534 - 1542. 
28. Bilek, S. E. (2010). The effect of time, temperature, solvent: solid and solvent composition on extraction of total phenolic compound from dried olive (Olea europaea L.) leaves. The Journal of Food, 35: $411-416$.

29. Tunchaiyaphum, S., Eshtiaghi, M. N. and Yoswathana, N. (2013). Extraction of bioactive compounds from mango peels using green technology. International Journal of Chemical Engineering and Applications, 4(4): $194-198$.

30. Cacace, J. E. and Mazza, G. (2003). Mass transfer process during extraction of phenolic compounds from milled berries. Journal of Food Engineering, 59: 379 - 389.

31. Herrero, M., Mendiola, J. A. and Ib, E. (2003). Subcritical water extraction of bioactive components from algae. Elsevier: pp. 534-560. 